\title{
A NÉPESSÉGMEGTARTÓ KÉPESSÉG KÉRDÉSKÖRE, VALAMINT KÍSÉRLET ANNAK SZÁMÍTÁSÁRA
}

\author{
Székely Andrea - Krajcsovicz Ágnes
}

\begin{abstract}
Absztrakt: A népességmegtartó képességet mint fogalmat gyakran emlegetjük a társadalomföldrajzban, azon belül is a külső és belsö migráció témakörében. Valamilyen nagyságú (szélsőséges esetben 0 ) népességmegtartó képessége minden lakott területnek van, így tehát nagyvárosnak, kisvárosnak, községnek, sőt a tanyáknak is. E munka arra vállalkozik, hogy mérhetővé tegye választott tényezőkön keresztül a népességmegtartó képességet. Ennek érdekében megalkottuk a népességmegtartási indexet, mely segít mérhetővé tenni a különbözö települések népességmegtartási képességét, melyet Tiszakécske és Tiszaföldvár példáján keresztül mutatunk be. Az eredmények azt jelzik, hogy Tiszakécske népességmegtartó képessége jobb, mint Tiszaföldváré.

Abstract: The retention ability is often used in human geography, mainly in the field of inner and outward migration. All territories have retention ability (in extreme case 0 ), so it can be interpreted for cities, towns, villages or even scattered farms. The research aim is to show a new method to measure the rural population retention ability through the newly developed retention ability index. We analyse the population retention ability through the example of Tiszakécske and Tiszaföldvár. Our results show higher retention ability in the case of Tiszakécske.
\end{abstract}

Kulcsszavak: népességmegtartó képesség, népességmegtartó index, vidékfejlesztés, Tiszakécske, Tiszaföldvár

Keywords: rural population retention ability, index of rural population retention ability, rural development, Tiszakécske, Tiszaföldvár

\section{Bevezetés}

A vidéki térségek amellett, hogy szerepük bizonyos szempontok számbavételénél felértékelődőben van (levegőtisztaság, kevesebb környezeti ártalom, erősebb társadalmi összetartás, egészségesebb életmód kialakítás és tevékenységi körök), számos komoly problémával küzdenek, mint elvándorlás, elöregedés. A vidéki és kisvárosi kutatások kapcsán többször felmerült az igény arra, hogy a települések népességmegtartó képességét vizsgálják, $\mathrm{s}$ a fogalom egyre többször jelenik meg manapság is a tudományos munkákban. Hazánkban a vidékfejlesztés a 2014-2020as periódusban igen nagy lendületet kap, s a Vidékfejlesztési stratégia vezérgondolata is a vidék felemelkedését célozza. (Magyarország Vidékfejlesztési Program 2014-2020). Épp ezért gondoljuk kulcsfontosságúnak, hogy egy olyan területet kezdjünk el újra feltárni, ami hasznos lehet a vidékfejlesztés újragondolásában és gyakorlati oldalról is segítheti a vidéki falvak, kisvárosok fejlesztését. A cikk célja az, hogy egy új metódust mutasson a népességmegtartás számítására. A népességmegtartási indexnek a szerzők által elnevezett fogalmat Tiszakécske és Tiszaföldvár városok esetében mutatjuk be. A települések népességmegtartásának számításának kérdésköre vélhetőleg szakmai vitát generál s ezáltal fejlödik a tudományos gondolkodás és a vidékfejlesztés témaköre gazdagodik. A cikkben bemutatásra kerülö módszer egy a lehetséges számítások közül, s mivel több tényezős modell, így valószínüsíthető a későbbi korrekciója. 


\section{A népességmegtartó képesség a hazai szakirodalmakban}

A községek népességmegtartó képességének fokozása, mint igény a VI. ötéves tervben jelent meg hivatalos dokumentumban. Ekkor pontos, tudományos tartalma még nem körülhatárolva. Erről elsők között Tóth (1982) cikkében olvashatunk: Szerinte a népességmegtartó képességnek két fontos tényezőnek kell megfelelnie. Egyrészt, hogy biztosítható legyen a teljes foglalkoztatás a lakóhelyen, vagy legyenek társadalmilag elfogadottak az ingázás feltételei. Másrészt pedig a lakosság alapellátását kell biztosítani, amelynek több összetevője is van. Ide tartozik az út- és járdahálózat, a lakáskörülmények mind mennyiségi, mind minőségi szempontból, a kereskedelmi ellátottság és forgalom, valamint az egészségügyi ellátás és az oktatási intézmények megléte. Ezeknek minél magasabb a színvonala és a kapacitása, annál erősebb az adott település megtartó képessége. Tóth megjegyzi azonban, hogy az erőforrások szükösségéből adódóan gyors fejlödésre nem lehet számítani, illetve ha a népességcsökkenést sikerülne is megállítani, a lakosság elöregedési folyamata akkor sem megállítható.

Matolcsi (1982) szintén több tényező eredendőjeként fogja fel a népességmegtartó képességet. Három alapvető funkciónak kell megfelelnie egy településnek: legyen megfelelö lakóhelyként, legyen elegendö munkahely, amely biztosítja a lakosság megélhetését, valamint legyen a közéletiség színtere, azaz legyen erős a társadalmi kohézió és a lakosok érzelmileg is kötődjenek lakhelyükhöz.

Néhány évvel később Bakos L-né et al. (1985) a népességmegtartó képesség szempontjából hasonló tényezőket vizsgált, mint Tóth. Figyelmet fordított az élve születés és a vándorlási egyenleg arányára, a közlekedés helyzetére - bár ő a tömegközlekedési lehetöségeket vizsgálta, illetve azt is figyelembe vette, hogy a megyeszékhelytől milyen távolságra van az adott település - a foglalkoztatási szerkezetre, a kereskedelmi kapcsolatokra, a lakáshelyzetre és a közmüellátottságra, az egészségügyi és szociális ellátottságra, valamint az intézményi ellátottság színvonalára

Salánczi és Fekete (1985) elsődleges tényezőként a foglalkoztatottságot vizsgálták. Eredményeik alapján azokon a településeken, ahol a munkalehetőség korlátozott, onnan a lakosság elvándorol és a település nem fejlödik. Ezt befolyásolja a mezőgazdasági és az ipari, valamint más munkalehetőségek megléte, vagy adott esetben hiánya. Megállapították, hogy az iparosítás bizonyos mértékben hat a népességmegtartó képességre, azonban ez a hatás nem mindenütt egyértelmü. Vizsgálódásuk eredményeként arra jutottak, hogy azokon a településeken, amelyek képesek fejlödni, és ahol nagyobb a foglalkoztatottság, az egy före jutó bruttó jövedelem és az éves munkabér, korszerübb a lakásállomány, jobb a kiskereskedelmi egységekkel, az egészségügyi és oktatási intézményekkel való ellátottság, ott nagyobb a népességmegtartó képesség és a lakosság száma növekedhet.

Csatári (1986) törekedett arra, hogy a népességmegtartó képesség meghatározásakor valamennyi számba vehető tényezöt figyelembe vegyen. Értelmezése szerint semmiképp sem jelentheti a falun élő népesség megtartását, hiszen míg az ország népessége fogy, addig ez abszurd célkitüzés lenne. 
Csatári (1986) szerint a népességmegtartó képesség mindenképpen különféle képességek együtteseként értelmezhető. Ezen képességek: a biológiai reprodukciós képesség, a település gazdasági eltartó képessége, az ellátó képesség különbözö tényezöi, valamint a településközösségnek és a településen élök ragaszkodásának a mértéke. A biológiai reprodukciós képesség szoros kapcsolatban áll az adott település demográfiai struktúrájával, a korösszetétellel és a vándorlással, elvándorlással, ugyanis ez utóbbi föként a szülőképes korosztályt érinti. A gazdasági eltartó képesség is több elemből tevődik össze: a foglalkoztatás mérete, kínálata, szerkezete, és magának a településnek jövedelemtermelő képessége.

Csatári (1986) meglátása szerint a mezőgazdaság átalakulásának, fejlödésének jelentős szerepe van a foglalkoztatás szerkezetében, ugyanis a mezőgazdaság gépesítésének természetes velejárója volt, hogy kevesebb ember szükséges a tényleges mezőgazdasági munkák elvégzéséhez, és a feleslegessé váló munkaerőt az iparnak kellett tovább foglalkoztatnia. A település ellátó képességének fogalma alatt a megközelítési időt és a tömegközlekedési járatsürüséget vizsgálta, amelyröl bebizonyosodott, hogy az igények folyamatosan nőnek, viszont sem a városokban, sem a kisebb településeken nem tudják kielégíteni a lakosok igényeit, ami elvándorláshoz vezethet. Pozitív példaként említi Tiszakécskét, ahol a vezetés képes volt fejleszteni és kockáztatott a sablonos, uniformizált terület- és településfejlesztési politika változtatásával. A negyedik tényező a településen élők ragaszkodása. Ez Csatári (1986) vizsgálatai alapján egyrészt függhet a régmúlt hagyományaitól, másrészt a társadalmi szervek müködésétől, a szemlélettől és az együttmüködési készségtől. Vizsgálatai alapján ennek a tényezőnek a hiánya befolyásolja legerősebben a népességmegtartó képességet.

Epstein (2001) a társadalmi összetartozás fontosságát hangsúlyozza, mivel a vidéki településeken a társadalmi kohézió jellemzően erősebb, ami vonzóvá teheti a vidéki életet a városokkal szemben, viszont megemlíti azt is, hogy vidéken, föként az elszigetelt kisebb településeken az információs technológia lassabban terjed, de ahol már elérhető, az tovább erősítheti a vidék vonzóerejét, mert általa könnyebb a világgal való kommunikáció.

Kis (2013) munkájában ugyan megnevezve nincs a népességmegtartás a vidékgazdaság rendszerszemléletében, de a szerző az infrastruktúra bemutatása és elemzése kapcsán felhívja a figyelmet annak fontosságára, mely így részét képezi, képezheti a vidék versenyképességének. Az infrastrukturális elemek megléte vagy hiánya már a korábban ismertetett szerzők (Bakos L-né et al., 1985; Tóth, 1982) munkáiban is helyet kap, és a szerzők is igen nagy fontosságot tulajdonítanak neki a népességmegtartási képesség vizsgálatakor.

Tikász (2007) elkészítette a népességmegtartó képesség rendszerét az Európai Környezeti Hivatal által használt környezetelemzési modell alapján: 


\section{1. ábra: A népességmegtartó képesség rendszere}

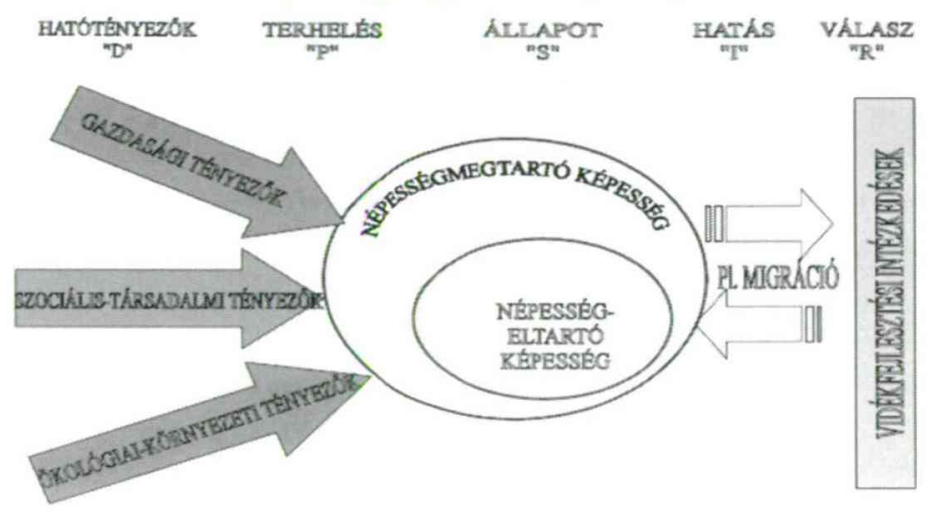

Forrás: Tikász (2007)

Az ábráról leolvasható, hogy Tikász (2007) szerint a népességmegtartó képességet jelentősen befolyásolják a vidéki területek funkciói, vagyis a gazdasági tényezők, a szociális-társadalmi tényezők és az ökológiai-környezeti tényezők. Ezeket sorolja a hatótényezők és a terhelés tényezői közé, amelyek hatással bírnak a népességmegtartó képességre.

$\mathrm{Az}$ állapot maga a megtartó képesség, amelynek egyik összetevője a vidék népességeltartó képessége, és amely több tényezö, képesség és adottság együtteseként alakulhat ki. A népességeltartó képességet meghatározza az egyes gazdasági ágaknak a település gazdasági szerkezetében betöltött szerepe, amelyek a lakosságnak megélhetést biztosítanak. Akkor mondható optimálisnak, ha a munkaerö kereslet és kínálat egyensúlyban van, valamint a helyi adottságokra alapozott a munkahelyteremtés. Második eleme a biológiai reprodukciós képesség, amelyet inkább az adottságok következményének tud be, nem pedig különálló adottságnak. Harmadik tényezőként az ellátó-képességet említi, amely alatt a lakosság igényeinek kielégítését és a megfelelö életkörülmények biztosítását érti. Negyedik tényező a vidéken élők ragaszkodása, érzelmi kötődése és identitás tudata. Ezeken kívül megemlíti még a politikai helyzet hatását és az ökológiai-környezeti jólétet.

Mindezek eredménye a hatás, vagyis maga a migráció. Ez kétirányú lehet, és minél erősebb a népességmegtartó képesség, annál inkább pozitív a vándorlási egyenleg. A válasz pedig - attól függően, hogy csökkenő, stagnáló, vagy növekvő a népesség - a vidékfejlesztési és egyéb fejlesztési intézkedések.

Jelenleg a népességmegtartó képességnek nincs általánosan elfogadott fogalma. Több szerző többféleképpen fogalmazta meg. Minden egyes bemutatott szerző fontos szempontnak tartotta az adott település jövedelemtermelö képességét, a foglalkoztatottság arányát, ám ellentmondások ebben is megjelentek, mert Csatári (1986) szerint inkább a mezőgazdaságot kellene fejleszteni, addig Salánczi és Fekete (1985) az ipar fejlődésében látja a megoldást. Gyakori elemek továbbá a tömegközlekedés, az egészségügyi rendszer és az oktatás fejlettsége, vagyis az 
infrastruktúra és az alapellátottság. hogy csak néhányan emelték ki a társadalmi kohéziót, az összetartozás fontosságát, amely egy nagyvárosban lényegesen gyengébb lehet, mint egy vidéki településen, vagyis a többség véleménye szerint a ragaszkodás, a szociális tényezők elhanyagolhatóak a téma szempontjából. Egy-egy helyen megjelent az információs technológia és az ökológia is, mint fontos tényezö. Ez azzal magyarázható, hogy ezek a tényezők a 21. században értékelődtek fel igazán, napjainkra azonban már olyan szintre jutott az információs technológiai fejlettsége, hogy bárhol elérhető, így ma már nem feltétlenül meghatározó tényező.

\section{Tiszakécske összehasonlítása Tiszaföldvárral}

Mindkét település esetében településfejlesztéshez készített megalapozó vizsgálatot használjuk forrásként: Tiszakécske: ITS DA Konzorcium, 2015; Tiszaföldvár: Diverzum Kft, 2016.

Tiszakécske Bács-Kiskun megye északkeleti sarkában fekszik. A település közigazgatási területe 13327 ha nagyságú, amelyböl 891 ha belterület. Tiszaföldvár Jász-Nagykun-Szolnok megye déli- részén elhelyezkedő város, melynek területe 8034 ha, és mindössze 12,3 km-re Tiszakécskétől. Mindkét település az Alföldön található, így domborzatát a szél és a folyók alakították ki. A folyószabályozások elött gyakori eset volt, hogy a Tisza elöntötte a területeket, így a magasabb területek voltak inkább lakottak (Tiszakécske ITS, 2015).

A lakónépesség csökkenő tendenciája a KSH adatai szerint folyamatos a csökkenő tendencia, habár Tiszakécskén 2015-ben minimális növekedés tapasztalható. Az alábbi diagram jól ábrázolja mindkét településen a csökkenő tendenciát:

\section{2. ábra: Tiszakécske és Tiszaföldvár lakosságának alakulása}

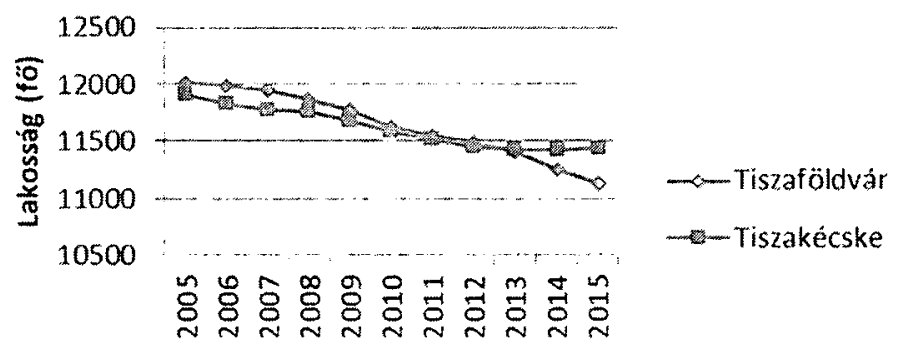

Év

Forrás: KSH (2017a)

Ez a minimális növekedés valószínüleg köszönhető annak, hogy Tiszakécske elvándorlási egyenlege pozitív volt az elmúlt 3 évben. Ezzel szemben Tiszaföldvárnál folyamatos a csökkenö tendencia. 
1. táblázat: Tiszakécske és Tiszaföldvár migrációja

\begin{tabular}{|c|c|c|c|c|}
\hline \multirow{2}{*}{ Év } & \multicolumn{2}{|c|}{ Odavándorlások (fö) } & \multicolumn{2}{c|}{ Elvándorlások (fö) } \\
\cline { 2 - 5 } & Tiszaföldvár & Tiszakécske & Tiszaföldvár & Tiszakécske \\
\hline 2011 & 209 & 183 & 218 & 196 \\
\hline 2012 & 184 & 158 & 191 & 162 \\
\hline 2013 & 192 & 174 & 196 & 150 \\
\hline 2014 & 178 & 193 & 248 & 169 \\
\hline 2015 & 179 & 204 & 209 & 164 \\
\hline
\end{tabular}

Forrás: KSH (2017b)

A település gazdaságát tekintve az iparosítási politikának köszönhetően napjainkban Tiszakécske ipari városnak tekinthető, míg Tiszaföldvárról ez nem mondható el (Tiszakécske ITS, 2015, Tiszaföldvár ITS, 2016). Az utóbbi esetében az iparosítás elmaradt, a lakosok inkább a közeli városokba (pl. Szolnok) jártak dolgozni, így Tiszaföldvár inkább agrárjellegű település maradt ahol a szántóföldi növénytermesztés és az állattenyésztés dominál. Tiszakécskén az ipar húzóágazatai a gépipar valamint az építőipar, míg a mezőgazdaság föként a növénytermesztésre és a halászatra korlátozódik (Tiszakécske ITS, 2015, Tiszaföldvár ITS, 2016).

A szolgáltatások szektorában Tiszakécske erős turizmusával emelkedik ki, amely a bőséges termálvízkészleten alapszik. Tiszaföldváron a szolgáltatások jelentős részét a kereskedelem és a gépjármüjavítás teszi ki, valamint jelentősek a szakmai, tudományos és müszaki tevékenységek is (Tiszakécske ITS, 2015, Tiszaföldvár ITS, 2016).

Tiszakécskén 5 darab óvoda található összesen 16 csoportszobával. Alapfokú oktatást két intézményben biztosítanak, az egyik állami, a másik egyházi múködtetésü. Mindkét intézményröl elmondható, hogy nincsenek kihasználva: 72 illetve $60 \%$-os kihasználtsággal müködnek, a diákok száma folyamatos csökkenést mutat. Középfokon ugyanabban a két intézményben tanulhatnak a diákok gimnáziumokban, valamint szakképzö iskola is található a városban, ám ennek képzési struktúrája nem illeszkedik kellöképpen a helyi gazdasági igényekhez. Tiszakécske rendelkezik egy kollégiummal is az állami iskola közvetlen közelében, ám alacsony kihasználtsággal müködik.

Tiszaföldváron 3 óvoda müködik, ezek fizikai állapota erösen leromlott. 3 általános iskola és 1 középiskola található. A középiskolában idegen nyelvi, informatikai és természettudományos szakirányú gimnáziumi képzés folyik, valamint humán szakgimnáziumi képzés folyik, ahol pedagógiai és családsegítö képzés, illetve szociális asszisztensi képzés folyik (Tiszakécske ITS, 2015).

Egészségügy szempontjából Tiszakécske rendelkezik egészségügyi központtal, melyen belül megtalálhatóak az alapellátáshoz és a szakellátáshoz kapcsolódó praxisok egyaránt. Összesen 5 háziorvosi, 2 gyermekorvosi és 3 fogorvosi praxis müködik jelenleg, továbbá van sebészet, kardiológia, ideggyógyászat, urológia, fülorr-gégészet, reumatológia, neurológia és belgyógyászati szakrendelés. A településen orvosi ügyelet müködik, amely a környező településeket is kiszolgálja. 
Tiszaföldváron szintén 5 háziorvos és 2 gyermekorvos dolgozik, de fogorvos csak 2 van és a szakellátások csak térítés ellenében vehetőek igénybe helyben (Tiszakécske ITS, 2015, Tiszaföldvár ITS, 2016).

A két település tömegközlekedésében is jelentős eltérések mutatkoznak: Tiszakécskén 46 buszmegálló található, amelyekkel a vasútállomás, az oktatási intézmények és a közintézmények könnyen megközelíthetőek. Átlagosan óránként legalább egy busz elhalad a megállókban, de a legforgalmasabb megállókban napi 60-70 járat áll meg. A városból közvetlen járatokkal elérhetőek olyan nagyobb városok, mint Kecskemét, Szolnok, Eger, Szeged, Nagykőrös és Budapest. Helyi autóbusz közlekedés nincs a településen, mert településen belül megoldható a közlekedés a helyközi járatokkal. Tiszaföldváron új autóbusz pályaudvar épült, ezen kívül 7 nagyobb forgalmú buszmegálló van, amelyeken legalább óránként 1 busz áthalad Szolnok irányába. Szeged és Kecskemét felé vannak még közvetlen buszok. Helyi járatos busz is van a településen hétfötől szombatig. Hétköznapokon 9 helyi járat, szombaton 5 járat indul a városon belül.

A vasúti közlekedés Tiszakécskén belül 4 megállóhelyen történik: Kerekdomb, Tiszakécske, Újbög, Óbög megállóhelyeken, melyek a Szolnok-Kecskemét vasútvonalon helyezkednek el. A várost érintő vasúti vonalon teher- és személyszállítás egyaránt történik. A személyszállító vonatok forgalma lényegesen kisebb, mint a buszoké. Naponta átlagosan 16 személyszállító vonat érinti a várost, és jegyárusítás nincs már egyik megállóhelyen sem. A vasútvonal állapota jellemzően rossz, néhol elfogadható, ezért mindenképp szükséges lenne egy átfogó felújítás, beruházás, amely rövidítené az utazási időt is. Tiszaföldvárnak egyetlen vasútállomása van, de annak az elhelyezkedése elég kedvezötlen. Közvetlen járatokkal elérhető Szolnok és Szentes és naponta egyszer Budapest is. A környező vasútvonalak jó állapotúak, így a vasúti közlekedés nem túl időigényes.

Az összehasonlításból látható, hogy habár nagyjából hasonló elhelyezkedésü, méretü és lakosságú településekröl beszélünk, Tiszakécske pozitívabb eredményeket mutat a szempontok többségében.

\section{A népességmegtartási index}

A források elemzése során nem találtunk példát a népességmegtartó képesség számszerüsítésére, mérhetővé tételére, ezért kidolgoztunk egy módszert, amelyben számszerüsíthetö a népességmegtartó képesség. A számítás kidolgozásához végig egy táblázatos, pontozásos módszert alkalmaztunk, amelyek egy részéhez már létező adatokat csoportosítottunk, másik részéhez pedig kérdőívezéssel szerezhetỏek adatok. Ehhez kapcsolódóan két kérdőívet készítettünk: mindkettőben a népességmegtartó index kiszámításához szükséges adatokat mértük fel Tiszakécskén és Tiszaföldváron. A kérdöíveket online töltettük ki tiszakécskei és tiszaföldvári lakosokkal. Ezek segítségével a két település népességmegtartási indexét ki lehet számolni.

A módszer lényege, hogy az öt - a szerzők által - kiválasztott szempont alapján (foglalkoztatás, tömegközlekedés, oktatás és egészségügyi szolgáltatások, a lakosság személyes kötődése, lakóhelyként való megfelelés) számszerüleg értékeli az egyes 
elemeket, s hozzájuk pontszámot rendel. Ahol lehet, ott országos, friss adatbázisokra támaszkodik, ahol ez nem lehetséges, ott saját készítésű, a lakosságot érintő kérdőívekkel jut adatokhoz), majd az adatok alapján hozzájuk pontértékeket rendel és súlyozott átlagukat veszi.

Kezdetnek meghatároztunk 5 szempontot, amely véleményünk szerint legerősebben befolyásolja a népességmegtartó képességet. Ezek az alábbiak:

1. Foglalkoztatás $(\mathrm{F})$

2. Tömegközlekedés (T)

3. Oktatás és egészségügyi szolgáltatások $(\mathrm{O})$

4. Személyes kötődés $(S)$

5. Lakóhelyként való megfelelés (L)

2. táblázat: A szempontok összesítése

\begin{tabular}{|l|c|c|c|}
\hline \multicolumn{1}{|c|}{ Szempont } & Jele & Minimum értéke & $\begin{array}{c}\text { Maximum } \\
\text { értéke }\end{array}$ \\
\hline Foglalkoztatás & $\mathrm{F}$ & 1 & 5 \\
\hline Tömegközlekedés & $\mathrm{T}$ & 1 & 5 \\
\hline $\begin{array}{l}\text { Oktatás és egészségügyi } \\
\text { szolgáltatások }\end{array}$ & $\mathrm{O}$ & 0 & 5 \\
\hline Személyes kötődés & $\mathrm{S}$ & 0 & 5 \\
\hline $\begin{array}{l}\text { Lakóhelyként való } \\
\text { megfelelés }\end{array}$ & $\mathrm{L}$ & 0 & 5 \\
\hline
\end{tabular}

Forrás: Saját szerkesztés

A népességmegtartási index ezen értékeknek súlyozott átlaga. A képletben az érték az eredményül kapott szám, a súlyozás pedig a felállított sorrend alapján történik, így az index minimum értéke 0,6 , a maximális értéke pedig 5:

Népességmegtartási index $=\frac{\mathrm{F} \cdot 5+\mathrm{T} \cdot 4+\mathrm{O} \cdot 3+\mathrm{S} \cdot 2+\mathrm{L} \cdot 1}{5+4+3+2+1}$

A módszer előnye, hogy mérhetővé és egyben összehasonlíthatóvá teszi az azonos településkategóriába eső települések népességmegtartási képességét. A gyakorlati életben orientálni képes a döntéshozókat és az összes érintettet, mely területen érdemes a fejlesztéseket elkezdeni vagy módosítani. A módszer hátránya, hogy igen komplex és időigényes az érték megállapítása, mivel a személyes kötődés szempont értékelése előzetes lakossági kérdőívezést igényel és kérdöíves minta nem biztos, hogy a reprezentativitás jegyeit magán fogja hordozni, így pedig torzulhat az eredmény is.

\section{A népességmegtartási index gyakorlati alkalmazása}

Elsődleges és legfontosabb szempontnak a foglalkoztatást tartjuk. A foglalkoztatás jelen esetben magába foglalja az adott településen nyilvántartott álláskeresők arányát a munkavállalási korú népesség arányában, valamint az átlagkeresetet. A Nemzeti Foglalkoztatási Szolgálat havonta frissíti az adatbázisát, amelyben településre 
bontva megtalálható a nyilvántartott álláskeresők száma, munkaképes korúak száma, és ezekből számítva az általuk relatív mutatónak nevezett arányszám, amely a két szám hányadosa százalékos formában. A másik tényező az átlagkereset, ehhez a KSH adatbázisát használtuk. A legkisebb területi egység a megye, amelyre elérhető a bruttó átlagkereset, így ebböl kiindulva alakítottunk ki egy 1-5-ös skálát, így a foglalkoztatás pontértékei az alábbiak szerint alakulhatnak:

\section{3. táblázat: A relatív mutatószámok pontértéke}

\begin{tabular}{|c|c|}
\hline A relatív mutató értéke (\%) & Az értékhez tartozó pontszám \\
\hline $0-5 \%$ & 5 \\
\hline $5-10 \%$ & 4 \\
\hline $10-15 \%$ & 3 \\
\hline $15-20 \%$ & 2 \\
\hline $20 \%$ felett & 1 \\
\hline
\end{tabular}

Forrás: Saját szerkesztés

1. bérkategória: $240000 \mathrm{Ft}$ felettiek ( 4 megye) -5 pont

2. bérkategória: $220000-240000 \mathrm{Ft}$ közöttiek (4 megye) - 4 pont

3. bérkategória: $200000-220000 \mathrm{Ft}$ közöttiek ( 5 megye) - 3 pont

4. bérkategória: $190000-200000 \mathrm{Ft} \mathrm{közöttiek} \mathrm{(4} \mathrm{megye)} \mathrm{-} 2$ pont

5. bérkategória: $190000 \mathrm{Ft}$ alattiak ( 3 megye) -1 pont

A foglalkoztatás értéke a két kapott pont átlaga:

Foglalkoztatás $=\frac{\text { A relatív mutató pontértéke }+ \text { a bruttó átlagkereset pontértéke }}{2}$

A Nemzeti Foglalkoztatási Szolgálat 2017.02.20-i adatbázisa alapján Tiszakécske relatív mutatója 3,49\%. Ehhez az értékhez tartozó pontszám 5. Tiszaföldváron ugyanez az érték 9,34\%, ami 4 pont. Mivel Tiszakécske egy BácsKiskun megyei település, így az átlagbérek alapján a 3. bérkategóriába tartozik, ami 3 pontot jelent. Tiszaföldvár pedig Jász-Nagykun-Szolnok megyei településként 2 pontot kap.

Ezek alapján az F értéke: Tiszakécskén $(5+3) / 2=4$; Tiszaföldváron $(4+2) / 2=3$

A második szempont a távolsági tömegközlekedés. Ezt azért tartjuk különösen fontosnak, mert ha egy település jó tömegközlekedéssel rendelkezik, könnyen elérhető egy másik település, akár egy nagyobb város is, akkor az emberek nem költöznek el egy kisebb településröl a kevés lehetőség miatt, hanem hajlandóak utazni akár a munkahelyük miatt, akár más lehetőség (pl. nagy bevásárló központok, szórakozási lehetőségek) miatt. Ehhez figyelembe vettük a buszok járatsürüségét és a vonatok közlekedését, az alapján, hogy milyen vasúti vonalon helyezkednek el: 
4. táblázat: Buszok járatsürüségének mérése

\begin{tabular}{|c|l|c|}
\hline $\begin{array}{c}\text { A buszjáratok száma } \\
\text { a településen naponta }\end{array}$ & \multicolumn{1}{|c|}{ Vasútvonal típusa } & $\begin{array}{c}\text { Az értékhez } \\
\text { tartozó pontszám }\end{array}$ \\
\hline 2000 felett & Transzeurópai hálózat & 5 \\
\hline $1001-2000$ & Országos törzshálózat & 4 \\
\hline $501-1000$ & Regionális vasúti pálya & 3 \\
\hline $51-500$ & Egyéb vasúti pálya & 2 \\
\hline 50 alatt & Nincs vasútállomás a településen & 1 \\
\hline
\end{tabular}

Forrás: Saját szerkesztés

A foglalkoztatáshoz hasonlóan itt is a két pontszám átlagából adódik a tömegközlekedés értéke:

Tömegközlekedés $=\frac{\text { A napi buszsürüség pontértéke }+ \text { a vasútvonal típusának pontértéke }}{2}$

A város településfejlesztési terve alapján Tiszakécske legforgalmasabb buszmegállóiban napi 60-70 busz halad át. Ez az 51-500-as kategóriába tartozik, ami 2 pontot jelent. Vasúti közlekedés szempontjából Tiszakécskénél egy regionális vasúti pálya halad el, ami 3 pontot ér. Tiszaföldváron naponta 84 busz számolható ( 2 pont), a vasútállomás pedig regionális vasúti pálya mentén található ( 3 pont), így Tiszakécskével megegyező értéket ért el.

Ezek alapján a T értéke: Tiszakécskén $(2+3) / 2=2,5$; Tiszaföldváron $(2+3) / 2=2,5$

5. táblázat: Oktatási és egészségügyi szolgáltatások elérhetősége

\begin{tabular}{|l|c|c|}
\hline \multicolumn{3}{|c|}{ Elérhetö-e a településen az alábbi szolgáltatás? 0-nem, 0,5-igen } \\
\hline \multicolumn{1}{|c|}{ Szempont } & Tiszakécske & Tiszaföldvár \\
\hline Bölcsőde & igen & igen \\
\hline Óvoda & igen & igen \\
\hline Általános iskola & igen & igen \\
\hline Gimnázium & igen & igen \\
\hline Szakképzö iskola & igen & igen \\
\hline Föiskola/ Egyetem & nem & nem \\
\hline Háziorvosi ellátás & igen & igen \\
\hline Szakorvosi ellátás & igen & nem \\
\hline Kórház & nem & nem \\
\hline $\begin{array}{l}\text { Szociális otthon, egyéb } \\
\text { szociális szolgáltatások }\end{array}$ & igen & igen \\
\hline
\end{tabular}

Forrás: Saját szerkesztés

A harmadik szempont az oktatás és az egészségügyi szolgáltatások vizsgálata. Nagyon fontosnak véljük ezt a szempontot, mert hiányuk nagy hátrányt jelent egy település számára. Az 5. táblázat tartalmazza a 2017-ben müködö intézményeket a 
két településen. Meglétük a népességmegtartási index számításunknál 0,5 pontot ér, hiányuk 0-t:

Ezek alapján az $O$ értéke: Tiszakécskén 8·0,5=4; Tiszaföldváron 7·0,5=3,5

A negyedik szempontunk a személyes kötődés. Ezt szintén táblázatos módszerrel oldottuk meg, amelyet a lakosság által töltettünk ki. Ennél a szempontnál 4 tényezöt különítettünk el, melyek közül kiemeljük a személyek miatti kötődést, mert az emberek többségének számára ez az a pont, ami a legerösebb kötődést eredményezi, ezért ez, a másik három alponttól eltérően dupla értékü. A kérdöíves megkérdezés után az adott alpontra érkező igenleges válaszok számát elosztjuk az összes válasz számával, majd a kiemelt egy esetnél megszorozzuk 2-vel, majd a 4 tényezö értékét összeadjuk.

Ehhez kapcsolódóan az alábbi eredményeket kaptuk a kérdőívek segítségével. A Tiszakécskén kitöltetett kérdőívre 91 válasz, a Tiszaföldváron kitöltetett kérdőívre 86 válasz érkezett.

6. táblázat: Oktatási és egészségügyi szolgáltatások elérhetôsége

\begin{tabular}{|l|c|c|c|c|}
\hline \multicolumn{4}{|c|}{ Önre igazak az alábbi állítások? 0-nem, 1 vagy 2-igen } \\
\hline \multirow{2}{*}{ Szempont } & $\begin{array}{c}\text { Tgen } \\
\text { válaszok } \\
\text { száma }\end{array}$ & Számítás & $\begin{array}{c}\text { Igen } \\
\text { válaszok } \\
\text { száma }\end{array}$ & Számítás \\
\hline $\begin{array}{l}\text { Személyek (család, } \\
\text { barátok, } \\
\text { ismerösök) miatt } \\
\text { kötődik a } \\
\text { településhez }\end{array}$ & 76 & $(76 / 91) \cdot 2=1,67$ & 68 & $(68 / 86) \cdot 2=1,58$ \\
\hline $\begin{array}{l}\text { A felmenök, } \\
\text { korábbi generációk } \\
\text { miatt kötődik a } \\
\text { településhez }\end{array}$ & 41 & $41 / 91=0,45$ & 53 & $53 / 86=0,62$ \\
\hline $\begin{array}{l}\text { A lakóhelye, } \\
\text { otthona miatt } \\
\text { kötődik a } \\
\text { településhez }\end{array}$ & 72 & $72 / 91=0,79$ & 65 & $65 / 86=0,76$ \\
\hline $\begin{array}{l}\text { Vonzó földrajzi } \\
\text { adottságok miatt } \\
\text { kötödik a } \\
\text { településhez }\end{array}$ & 54 & $54 / 91=0,59$ & 18 & $18 / 86=0,19$ \\
\hline
\end{tabular}

Forrás: Saját szerkesztés

Ezek alapján az $S$ értéke: Tiszakécskén $\quad 1,67+0,45+0,79+0,59=3,5$; Tiszaföldváron $1,58+0,62+0,76+0,19=3,15$

Az ötödik, vagyis utolsó szempontunk a település lakóhelyként való megfelelése. Az előzőekhez hasonlóan táblázatos módszerrel oldottuk meg. A 
tényezőket két részre bontottuk: 7 tényező a lakosság megkérdezése nélkül értékelhetö, a maradék három pedig kérdőíves megkérdezéssel, a személyes kötődéssel megegyezően értékelhető.

7. táblázat: Lakóhelyként való megfelelés

\begin{tabular}{|l|c|c|}
\hline \multicolumn{2}{|c|}{ Találhatóak-e az alábbiak a településen? 0-nem, 0,5-igen } \\
\hline \multicolumn{1}{|c|}{ Szempont } & Tiszakécske & Tiszaföldvár \\
\hline $\begin{array}{l}\text { Mobil, kábelTV, internet } \\
\text { lefedettség }\end{array}$ & igen & igen \\
\hline $\begin{array}{l}\text { Étterem, kávézó, egyéb } \\
\text { szórakozó helyek }\end{array}$ & igen & igen \\
\hline Franchise típusú éttermek & nem & nem \\
\hline Kisboltok, piac & igen & igen \\
\hline Élelmiszerkereskedelmi láncok & igen & igen \\
\hline $\begin{array}{l}\text { Pláza, bevásárlóközpont, egyéb } \\
\text { szakirányú üzletek (pl. } \\
\text { ruházati, informatikai) }\end{array}$ & igen & igen \\
\hline $\begin{array}{l}\text { Ügyintézési helyek (pl. } \\
\text { Kormányablak, posta, bank) }\end{array}$ & igen & $(26 / 86) \cdot 0,5=0,15$ \\
\hline \multicolumn{1}{|c|}{ Igazak-e az alábbi állítások a településre? 0-nem,1-igen } \\
\hline $\begin{array}{l}\text { Jó a közbiztonság, alacsony } \\
\text { bünözési ráta }\end{array}$ & $(70 / 91) \cdot 0,5=0,38$ & $(53 / 86) \cdot 0,5=0,31$ \\
\hline $\begin{array}{l}\text { Találhatóak tiszta, szép } \\
\text { zöldterületek a városon belül és } \\
\text { közvetlen környékén }\end{array}$ & $(88 / 91) \cdot 0,5=0,48$ & $(28 / 86) \cdot 0,5=0,16$ \\
\hline $\begin{array}{l}\text { A település tiszta, rendezett, } \\
\text { kellemes környezetet nyújt }\end{array}$ & $(84 / 91) \cdot 0,5=0,46$ & \\
\hline
\end{tabular}

Forrás: Saját szerkesztés

Ezek alapján az L értéke: Tiszakécskén $6 \cdot 0,5+0,38+0,48+0,46=4,32$; Tiszaföldváron $6 \cdot 0,5+0,15+0,31+0,16=3,62$

A népességmegtartási index ezeknek a súlyozott átlaga. A képletben az érték az eredményül kapott szám, a súlyozás pedig a felállított sorrend alapján történik, így a minimum értéke 0,6 , a maximális értéke pedig 5:

Népességmegtartási index $=\frac{\mathrm{F} \cdot 5+\mathrm{T} \cdot 4+\mathrm{O} \cdot 3+\mathrm{S} \cdot 2+\mathrm{L} \cdot 1}{5+4+3+2+1}$

A megkapott értékek alapján már kiszámítható Tiszakécske és Tiszaföldvár népességmegtartó képessége: 
Tiszakécske:

Népességmegtartási index $=\frac{4 \cdot 5+2,5 \cdot 4+4 \cdot 3+3,5 \cdot 2+4,32 \cdot 1}{5+4+3+2+1}$

Tiszaföldvár:

Népességmegtartási index $=\frac{3 \cdot 5+2,5 \cdot 4+3,5 \cdot 3+3,15 \cdot 2+3,62 \cdot 1}{5+4+3+2+1}$

Tiszakécske népességmegtartási indexe tehát 3,55, míg Tiszaföldváré 3,03. Tiszakécske ezzel jelentősen elmarad a maximális értéktől, azonban úgy gondolom, kisvárosként ez egy erős eredmény, föleg ha figyelembe vesszük, hogy a két település mennyire hasonló, mégis Tiszaföldvár 0,52-vel elmarad. Ez azt jelenti, hogy Tiszakécske méretéhez, adottságaihoz képest erős népességmegtartó képességgel rendelkezik. Természetesen vannak továbbra is fejlesztésre szoruló területek.

\section{6. Összefoglalás}

A népességmegtartó képesség tehát egy olyan összetett fogalom, amely a lakosok az adott településen való maradását célozza meg, és több tényező is fontos szerepet játszik ennek befolyásolásában, melyek a foglalkoztatás, a tömegközlekedési lehetôségek, az oktatási és egészségügyi szolgáltatások, a személyes kötődés és a lakóhelyként való megfelelés. Ez a megfogalmazás hasonló, azokhoz, amelyeket a szakirodalomban találhatunk, azonban nem egyezik azokkal. Nincs egységesen elfogadott definíció a népességmegtartó képességre, és azok a szakirodalmak, amelyeket felhasználtunk több szempontban egyeznek, vannak átfedések közöttük, mégis eltérő szempontokat határoztak meg befolyásoló tényezőkként. Ugyanígy a saját készítésü definícióban is vannak a szakirodalommal megegyező és eltérö tényezők.

Ahhoz, hogy mérhetö, számszerüsíthető legyen a népességmegtartó képesség, kidolgoztunk egy módszert, amely jelenlegi változatában egy nyers mutatószámot ad eredményül, de könnyen használható és kiszámítható vele egy település népességmegtartó képessége. Azért gondoljuk, hogy ez fontos lehet, mert így a települések népességmegtartó képessége összehasonlítható.

Azért is hasznos lehet ez a módszer, mert az eredményekből leszürhető az, hogy melyik az a terület, amelyen fejlesztés szükséges egy adott településen, mire kell több energiát és figyelmet fordítani. Ez segíthet abban, hogy megálljon a vidék elnéptelenedése, elöregedése.

Tiszakécske összességében nagyon jó adottságokkal rendelkezik. Méretéhez és lakosságához mérten egy erösen pozitív kép alakul ki róla, ami köszönhető jó természeti adottságainak, szerencsés földrajzi elhelyezkedésének, az iparosítás időben való elkezdésének, és az azóta is tartó folyamatos fejlődésnek. A népességmegtartási indexe a kialakított számítási módszer alapján 3,55. A hasonlítás alapjául szolgáló Tiszaföldváré mindössze 3,03. Mindkét település elmarad a maximális 5-ös értéktől, de Tiszakécske eredménye jól mutatja, hogy mennyivel 
erősebb és vonzóbb település más hasonló méretű és hasonló tulajdonságú településnél.

\section{Irodalomjegyzék}

Bakos L-né et al. (1985): A szomszédos megyék középfokú vonzáskörzetébe tartozó települések Hajdú-Bihar megyei helyzete és népességmegtartó-képessége. Területi statisztika, 35 (3): 295315.

Csatári B. (1986): A községek népességmegtartó képességének fö tényezői az Alföldön. In: Novák L., Selmeczi L. (szerk.): Falvak, mezövárosok az Alföldön. Arany János Múzeum, Nagykörös, 779-784.

Diverzum Kft (2016): Tiszaföldvár város településfejlesztési koncepciójának és integrált településfejlesztési stratégiájának megalapozó vizsgálata. Budapest.

Enyedi Gy. (1995.): Városverseny, várospolitika, városmarketing. Tér és Társadalom, 9 (1-2): 1-3.

T. S. Epstein (2001): Development- There is another way: A rural-urban partnership develpoment paradigm. World Development, 29 (8): 1443-1454.

Földmüvelésügyi Minisztérium (2012): Nemzeti Vidékstratégia 2012-2020. Földmủvelésügyi Minisztérium, Budapest.

ITS DA Konzorcium (2015): Tiszakécske város integrált településfejlesztési stratégiajja-megalapozó vizsgálat. Budapest.

Kis K. (2013): Vidékgazdaság, erőforrások, infrastruktúra rendszerszemléletben. In: Veres L. (szerk.): Regionális földrajzi tanulmányok: Abonyiné Dr. Palotás Jolán 70. születésnapja tiszteletére. Egyesület Közép-Európa Kutatására, Szeged. 109-120.

KSH (2017a): http://statinfo.ksh.hu/Statinfo/haViewer.jsp (2017.01.09.)

KSH (2017b): http://statinfo.ksh.hu/Statinfo/haViewer.jsp (2017.01.09.)

Matolcsi L. (1982): Az urbanizáció hatása a közigazgatásra, egy középfokú szerepkörü település tükrében. Szakdolgozat, Budapest.

Miniszterelnökség Agrár- és Vidékfejlesztési Programokért Felelős Helyettes Államtitkárság (2014): Magyarország - Vidékfejlesztési Program 2014-2020. Miniszterelnökség Agrár- és Vidékfejlesztési Programokért Felelös Helyettes Államtitkárság, Budapest.

Salánczi I.- Fekete T. (1985): A településfejlesztés és a falusi népesség változásának összefüggései Györ-Sopron megyében. Területi statisztika, 35 (3): 331-342.

Tikász I. E. (2007): A vidék népességmegtartó és népességeltartó képességének egyes elemei a püspökladányi kistérségben. Doktori értekezés, Debrecen.

Tóth K. (1982): Tények és érvek a Békés megyei községek népességmegtartó képességéről. Terïleti statisztika, 32 (1-2): 40-59. 